\title{
SOME EFFECTS OF A SINGLE INJECTION OF CHLORMADINONE ACETATE OR METHALLIBURE ON SEXUAL FUNCTION IN THE PUBESCENT MALE ANIMAL
}

\author{
II. THE RABBIT \\ J. D. SKINNER* AND C. E. ADAMS \\ A.R.C. Unit of Reproductive Physiology and Biochemistry, \\ University of Cambridge $\dagger$
}

(Received 3rd February 1969)

\begin{abstract}
Summary. The effect of CAP and of methallibure on sexual function was studied in the male rabbit. GAP was given as a single subcutaneous injection ( $2 \mathrm{mg}$ or $10 \mathrm{mg} / \mathrm{kg}$ body weight) and methallibure as a single intravenous injection ( $1 \mathrm{mg}$ or $10 \mathrm{mg} / \mathrm{kg}$ body weight) at birth, 42 days of age (before the onset of spermatogenesis) and at 63 days of age (after the onset of spermatogenesis). Surgically castrated males and controls were included for comparison. All bucks were subjected to autopsy at 133 days of age, 1 week after the appearance of spermatozoa in the ejaculate of the controls.

Both drugs suppressed male behaviour and testicular growth. Growth rate was adversely affected in bucks treated at birth or 42 days of age. The effect of the drugs was not so marked when given after the onset of spermatogenesis.
\end{abstract}

\section{INTRODUCTION}

Prolonged treatment with progesterone or chlormadinone acetate (CAP, 6-chloro-6-17-acetoxyprogesterone) suppresses both libido and spermatogenesis in mature rabbits (Ericsson, Dutt \& Archdeacon, 1964). Jöchle \& Schilling (1965) found that GAP exerts a long-acting depot effect in the boar and that puberty can be delayed by a single injection of the drug. Continuous treatment with methallibure (ICI 33828, 1-( $\alpha$-methyl, allyl $)-6$-methyl-dithiobiurea) causes atrophy of the testis and accessory glands in the rat (Paget, Walpole \& Richardson, 1961; Walpole, 1965). In cocks, daily ingestion of this compound leads to sterility, and it has been suggested that this treatment could be used for controlling aggressive behaviour (EI Jack \& Sykes, 1965). The object of the present experiment was to investigate the possibility of inhibiting sexual development and aggressive behaviour in the pubescent rabbit using a single injection of either CAP or methallibure.

* Present address: Research Institute for Animal and Dairy Science, Private Bag, Irene, South Africa.

† Postal address: Animal Research Station, 307 Huntingdon Road, Cambridge CB3 0JQ. 


\section{MATERIALS AND METHODS}

CAP and methallibure were injected in crystalline suspension at three stages, namely at birth, at 42 days of age (before the onset of spermatogenesis) and at 63 days of age (after the onset of spermatogenesis). Two dosage levels were used. CAP was injected subcutaneously at $2 \mathrm{mg} / \mathrm{kg}$ body weight ('low' level) and $10 \mathrm{mg} / \mathrm{kg}$ body weight ('high' level), while methallibure was injected intravenously at $1 \mathrm{mg} / \mathrm{kg}$ ('low') and $10 \mathrm{mg} / \mathrm{kg}$ ('high'), respectively. Since intravenous injection proved extremely difficult in some new born rabbits, the 'low' dose of methallibure was omitted in this group. Further groups of animals were surgically castrated at birth, 42 , or 63 days of age in order to compare their growth with that of animals receiving the two drugs.

The design of the experiment was a randomized block with three blocks of sixteen treatments. Forty-eight rabbits were allocated randomly to the different groups. After weaning and transfer to colony pens, the behaviour of the rabbits was observed and the first attempts at mounting (copulatory behaviour) were noted.

From about 90 days of age, many of the rabbits had to be separated into smaller groups and some had to be placed in single pens as they became aggressive and attacked their companions. This occurred first in the entire, untreated animals but later also in some of the treated bucks. Weaker rabbits were penned together and large docile bucks were kept in another group.

When mounting was observed, ejaculates were collected from the control bucks and these animals were killed 1 week after the appearance of spermatozoa, which occurred at 126 days of age. The reproductive tracts were dissected out and examined. Spermatozoa from each cauda epididymidis were counted, their motility was estimated and the concentration of fructose and citric acid in the gl. vesicularis and gl. seminalis was determined (Mann, 1964). Slices of testis were fixed in Bouin's fluid and after routine paraffin embedding, sectioned and stained with Delafield's haematoxylin and chromotrope $2 \mathrm{R}$ for later histological examination and measurement of seminiferous tubule diameter. All of the rabbits were weighed regularly throughout the experimental period.

\section{RESULTS}

The mean values for the various parameters under study are presented in Tables 1, 2 and 3. In Table 1, all measurements have been combined for statistical convenience. As the stage of injection had a significant influence on the results obtained, the overall mean for drug effects could not be compared with the controls. The following points are of particular interest:

(a) Male behaviour was significantly delayed both by GAP and methallibure.

(b) The stage of injection was important. The injections of CAP at birth resulted in smaller tubules, lower caudal sperm count and lower motility than when given later. Vesicular fructose levels were, however, higher in the CAPtreated animals than in the controls, possibly as a result of the 'rebound' phenomenon. Injections at 42 days depressed the caudal sperm count as well as sperm motility. The injection of methallibure at birth had the same effect as that of CAP. Injections of methallibure at 42 days of age depressed tubule 
diameter, number and motility of caudal spermatozoa, and the fructose content of the accessory glands.

(c) The growth rate of CAP-treated rabbits injected at birth and at 42 days of age was lower than that of either the entire or the castrated bucks. This treatment may have had an adverse effect on the growth rate of this group

TABLE 1

THE EFFECT OF GHLORMADINONE ACETATE AND METHALLIBURE ON SEXUAL FUNGTION IN THE PUBESCENT MALE RABBIT

\begin{tabular}{|c|c|c|c|c|}
\hline & Control $(C)$ & $\begin{array}{c}\text { Chlormadinone } \\
(A)\end{array}$ & $\begin{array}{c}\text { Methallibure } \\
(B)\end{array}$ & S.E. \\
\hline $\begin{array}{l}\text { Age at first mounting (days) } \\
\text { Weight of testes }(\mathrm{g}) \\
\text { Diameter of seminiferous tubules }(\mu) \\
\text { Weight of epididymides }(\mathrm{g}) \\
\text { No. of cauda spermatozoa }\left(\times 10^{6}\right) \\
\text { Motility of cauda spermatozoa }(\%) \\
\text { Weight of gl. seminalis and vesicularis }(\mathrm{g}) \\
\text { Fructose concentration }(\mathrm{mg} / 100 \mathrm{~g}) \\
\text { Fructose content }(\mathrm{mg}) \\
\text { Gitric acid concentration }(\mathrm{mg} / 100 \mathrm{~g}) \\
\text { Gitric acid content }(\mathrm{mg}) \\
\text { Weight of ampullae }(\mathrm{g}) \\
\text { Weight of prostate }(\mathrm{g})\end{array}$ & $\begin{array}{c}73 \cdot 8 \\
3 \cdot 82 \\
166 \dagger \\
1 \cdot 49 \\
2 \cdot 62 \\
\mathbf{4 3 \cdot 6} \\
1 \cdot 72 \\
\mathbf{7 0 \cdot 8} \\
1 \cdot 31 \\
124 \cdot 0 \\
2 \cdot 59 \\
0 \cdot 38 \\
0 \cdot 43\end{array}$ & $\begin{array}{c}97 \cdot 1 * * \\
3 \cdot 11 \\
154 \\
1 \cdot 43 \\
2 \cdot 53 \\
25 \cdot 3 \\
1 \cdot 72 \\
\mathbf{8 4} \cdot 1 \\
1 \cdot 67 \\
106 \cdot 2 \\
2 \cdot 60 \\
0 \cdot 37 \\
0 \cdot 41\end{array}$ & $\begin{array}{c}97 \cdot 1 * * \\
3 \cdot 40 \\
\mathbf{1 6 4} \\
1.48 \\
\mathbf{3} \cdot 18 \\
\mathbf{3 1 \cdot 9} \\
1.69 \\
\mathbf{7 2 \cdot 0} \\
\mathbf{1} \cdot 33 \\
84 \cdot 8 \\
1.50 \\
0.38 \\
0 \cdot 45\end{array}$ & $\begin{array}{l}4 \cdot 40 \\
0.25 \\
6 \cdot 4 \\
0 \cdot 11 \\
0.79 \\
5 \cdot 1 \\
0 \cdot 19 \\
7 \cdot 43 \\
0.23 \\
17 \cdot 5 \\
0.55 \\
0.04 \\
0 \cdot 04\end{array}$ \\
\hline
\end{tabular}

$* * 0.001<P<0.01$.

+ Values in bold type refer to those parameters which were markedly affected by stage of treatment (see Table 2).

throughout the remainder of the experiment. The rabbits injected at birth had an average daily weight gain of $14.7 \mathrm{~g}$ as compared with $25.7 \mathrm{~g}$ for entire control bucks up to weaning, a difference which was highly significant $(P<0.001)$. Although the difference between the castrated and entire, untreated bucks was not significant, the surgically-castrated bucks had a much

TABLE 2

INFLUENCE OF A SINGLE INJEGTION OF CHLORMADINONE ACETATE OR METHALLIBURE ON GROWTH RATE, EXPRESSED AS MEAN DAILY GAIN IN G, IN MALE RABBITS

\begin{tabular}{|c|c|c|c|c|c|c|c|c|c|c|}
\hline \multirow{2}{*}{$\begin{array}{c}\text { Treatment group } \\
\text { (Time of treatment) }\end{array}$} & \multirow{2}{*}{ Entire } & \multicolumn{3}{|c|}{ Castrated } & \multicolumn{3}{|c|}{$C A P(L$ and $H)$} & \multicolumn{3}{|c|}{ Methallibure $(L$ and $H)$} \\
\hline & & Birth & 42 days & 63 days & Birth & 42 days & 63 days & Birth & 42 days & 63 days \\
\hline $\begin{array}{l}0 \text { to } 42 \text { days } \\
42 \text { to } 63 \text { days } \\
63 \text { to } 126 \text { days }\end{array}$ & $\begin{array}{l}25 \cdot 7 \\
18 \cdot 7 \\
19 \cdot 9\end{array}$ & $\begin{array}{l}23 \cdot 7 \\
14 \cdot 6 \\
20 \cdot 1\end{array}$ & $\begin{array}{l}23 \cdot 2 \\
20 \cdot 8 \\
20 \cdot 0\end{array}$ & $\begin{array}{l}26 \cdot 4 \\
15 \cdot 9 \\
19 \cdot 4\end{array}$ & $\begin{array}{l}14 \cdot 7 \\
18 \cdot 1 \\
21 \cdot 4\end{array}$ & $\begin{array}{l}18 \cdot 8 \\
22 \cdot 4 \\
18 \cdot 0\end{array}$ & $\begin{array}{l}27 \cdot 6 \\
18.0 \\
16.7\end{array}$ & $\begin{array}{l}26 \cdot 7 \\
15 \cdot 7 \\
18 \cdot 3\end{array}$ & $\begin{array}{l}19 \cdot 0 \\
15.7 \\
18 \cdot 6\end{array}$ & $\begin{array}{l}28 \cdot 3 \\
18 \cdot 1 \\
17 \cdot 6\end{array}$ \\
\hline
\end{tabular}

larger amount of omasal fat at autopsy which would have produced a bigger difference in carcase weight in favour of the entire bucks. The growth rate of the bucks injected at 42 days with methallibure was also reduced. This group appeared to be markedly affected by injections at this stage. 


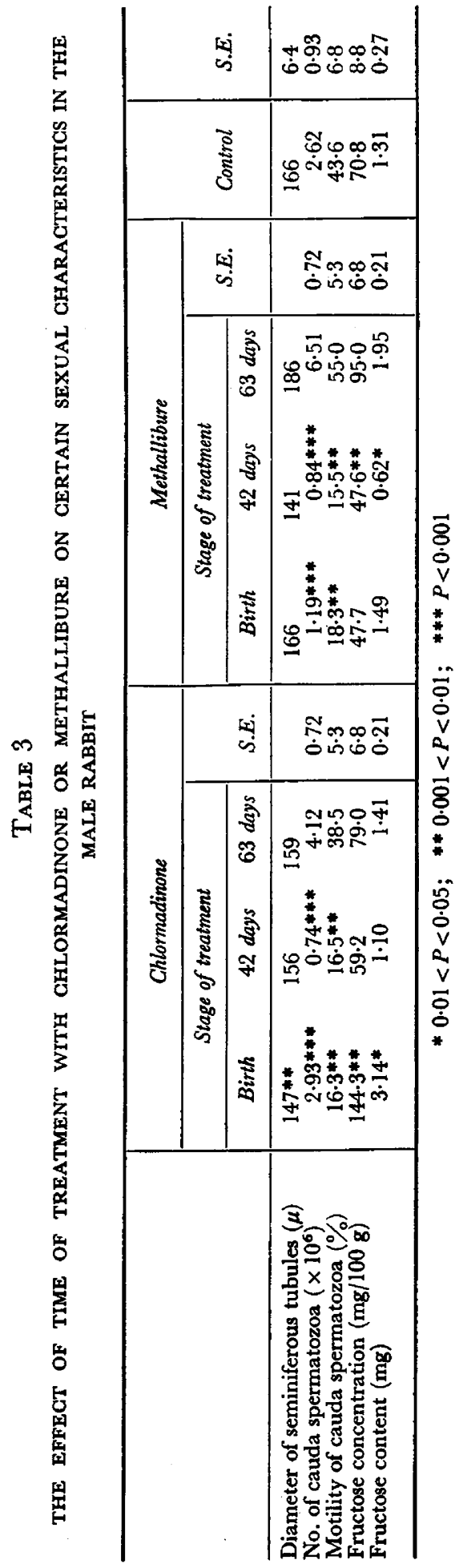




\section{DISCUSSION}

Injections of CAP after the onset of spermatogenesis had no apparent effect on sexual function in the rabbit, apart from delaying the onset of male behaviour which, in fact, occurred in all treated bucks. This suppression of libido and aggressive behaviour is in agreement with reports of the effect of CAP on mature rabbits (Ericsson et al., 1964) and of methallibure on the cock (El Jack \& Sykes, 1965).

Neonatal injections of CAP had a marked, and apparently reversible, effect on sexual function. However, not only was sexual function affected at this stage but also growth rate, possibly indicating a wider inhibition of pituitary function. Gampbell (1965) injected three male rabbits neonatally with $200 \mathrm{mg}$ progesterone and killed them at 93 days of age. These rabbits showed no significant difference from control bucks with regard to age at first copulation, final body weight, or testis weight.

The growth rate of bucks injected at 42 days of age was also significantly affected by both GAP and methallibure. The latter group was also severely retarded with regard to sexual function, indicating that the pituitary gland may be more susceptible to drugs at some stages than at others. Poppe's (1932) observation that the amount of omasal fat is greater in surgically castrated rabbits was confirmed.

The present results, as in the ram (Skinner \& Rowson, 1969), support the hypothesis that progestagens inhibit gonadotrophin secretion and that, after the form of treatment described, reproductive processes return to normal in due course. CAP might be used to control aggressive behaviour in colonyreared rabbits, though the suppression of growth rate in animals treated in the neonatal period could be disadvantageous.

\section{ACKNOWLEDGMENTS}

We would like to thank Dr H. M. Dott and Professor T. Mann for their interest in this work, Mr J. C. Rowell for assisting with the design of the experiments and for carrying out the statistical analysis, and Dr W. Jöchle, Syntex Research, and Dr A. Walpole of ICI for the gifts of CAP and methallibure. One of us (J.D.S.) is indebted for a scholarship to British Petroleum (Southern Africa).

\section{REFERENCES}

CAmprelL, H. J. (1965) Effects of neonatal injections of hormones on sexual behaviour and reproduction in the rabbit. F. Physiol., Lond. 181, 568.

EL JACK, M. H. \& SyKes, A. H. (1965) Effect of a dithiobiurea derivative on semen characteristics and fertility in the fowl. $\mathcal{F}$. Reprod. Fert. 10, 79.

Ericsson, R. J., DutT, R. H. \& Archdeacon, J. W. (1964) Progesterone and 6-chloro-6-17-acetoxyprogesterone as inhibitors of spermatogenesis in the rabbit. Nature, Lond. 204, 261.

Jöchle, W. \& Schilling, E. (1965) Experience with progestagens in farm animals. F. Reprod. Fert. 10, 287.

Mann, T. (1964) Biochemistry of semen and of the male reproductive tract, 2nd edn. Methuen, London.

Paget, G. E., Walpole, A. L. \& Richardson, D. N. (1961) Non-steroid inhibitors of pituitary gonadotrophic function. Nature, Lond. 192, 1191. 
Poppe, W. R. (1932) Über die Einwirkung der Kastration auf des Knochensystem des Kaninchens. Kühn-Arch. 34, 61.

Skinner, J. D. \& Rowson, L. E. A. (1969) Some effects of a single injection of chlormadinone acetate or methallibure on sexual function in the pubescent male animal. I. The ram. F. Reprod. Fert. $20,95$.

WALPOLE, A. L. (1965) Non-steroidal agents inhibiting pituitary gonadotrophic function. In: A Symposium on Agents Affecting Fertility, p. 159. Ed. C. R. Austin and J. S. Perry. Churchill, London. 